This article was downloaded by: [Canadian Research Knowledge Network]

On: 31 July 2009

Access details: Access Details: [subscription number 783016864]

Publisher Routledge

Informa Ltd Registered in England and Wales Registered Number: 1072954 Registered office: Mortimer House, 37-41 Mortimer Street, London W1T 3JH, UK

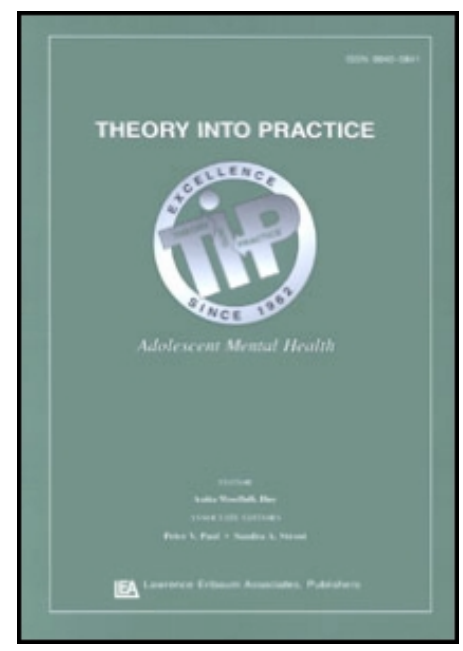

\title{
Theory Into Practice
}

Publication details, including instructions for authors and subscription information:

http://www.informaworld.com/smpp/title content=t775653706

\section{Voices of Queer Youth in Urban Schools: Possibilities and Limitations}

Mollie V. Blackburn a; Lance T. McCready ${ }^{b}$

${ }^{a}$ The Ohio State University, ${ }^{\mathrm{b}}$ Ontario Institute for Studies in Education, University of Toronto,

Online Publication Date: 01 June 2009

To cite this Article Blackburn, Mollie V. and McCready, Lance T.(2009)'Voices of Queer Youth in Urban Schools: Possibilities and Limitations', Theory Into Practice,48:3,222 - 230

To link to this Article: DOI: $10.1080 / 00405840902997485$

URL: http://dx.doi.org/10.1080/00405840902997485

\section{PLEASE SCROLL DOWN FOR ARTICLE}

Full terms and conditions of use: http://www.informaworld.com/terms-and-conditions-of-access.pdf

This article may be used for research, teaching and private study purposes. Any substantial or systematic reproduction, re-distribution, re-selling, loan or sub-licensing, systematic supply or distribution in any form to anyone is expressly forbidden.

The publisher does not give any warranty express or implied or make any representation that the contents will be complete or accurate or up to date. The accuracy of any instructions, formulae and drug doses should be independently verified with primary sources. The publisher shall not be liable for any loss, actions, claims, proceedings, demand or costs or damages whatsoever or howsoever caused arising directly or indirectly in connection with or arising out of the use of this material. 


\section{Voices of Queer Youth in Urban Schools: Possibilities and Limitations}

This article reviews scholarship that represents urban students who self-identify as lesbian, gay, bisexual, transgender, queer, or questioning. It draws on empirical examples to illustrate prominent themes across this scholarship, including the homophobia they experience, the impact it has on their academic performance, and the activism it sparks. Finally, it considers implications for urban educators working with queer youth, specifically, the need to understand and be prepared to address multiple social and cultural issues that intersect with sexual and gender identities.

Mollie V. Blackburn is an associate professor of education at The Ohio State University; Lance T. McCready is an assistant professor at the Ontario Institute for Studies in Education, University of Toronto.

Correspondence should be addressed to Mollie V. Blackburn, Teaching and Learning, The Ohio State University; 200 Ramseyer Hall, 29 W. Woodruff Ave., Columbus, OH 43210. E-mail: Blackburn.99@osu.edu
$\mathrm{U}$ RBAN COMMUNITIES AND SCHOOLS are home to a wide array of social and support services by and for queer youth in and out of school. For example, there is San Francisco's Lavender Youth Recreation and Information Center (LYRIC; Consolacion, 2001) and The Attic Youth Center in Philadelphia (Blackburn, 2004), among many other community-based organizations beyond school walls. Some services are offered at schools, but outside of official curricula, such as Los Angeles' Project 10 (Uribe, 1995) and gay-straight alliances (GSAs) across North America (Lee, 2002). Many of these GSAs are housed in metropolitan-area secondary schools. Moreover, many cities, like Toronto, for example, have large GSA networks that include multiple high school programs. In addition, there is evidence of teachers' and administrators' efforts to combat heterosexism and homophobia in their classrooms, schools, and districts (Cohen \& Chasnoff, 1997); there is even the Harvey Milk School in New York City and the Triangle Pro- 
gram in Toronto, which are designed specifically to provide a safe and supportive academic environment for lesbian, gay, bisexual, transgender, and questioning (LGBTQ) youth (http://www. hmi.org/). The Milwaukee Public School System has approved, unanimously, the nation's first gay-friendly middle school (US News \& World Report, 2008). Given these services, one might assume that urban communities and schools are meeting the needs of queer youth, especially in comparison to suburban and rural locales. In fact, the Gay, Lesbian and Straight Education Network's (GLSEN) most recent national school climate survey (Kosciw, Diaz, \& Greytak, 2008) has suggested that "students in small town and rural schools were less likely to have access to LGBT-related resources and supports than students in urban and suburban schools" (p. 94). The voices of queer urban youth, however, suggest a more complicated story.

We turn to scholarship that captures youth voices from San Francisco and the Bay Area of California, the New York metropolitan area, Atlanta, Memphis, Salt Lake City, Philadelphia, Chicago, and an unnamed Midwestern city to illustrate this point. We pull together diverse voices talking about their experiences in these cities across time, albeit almost exclusively within the 21 st century, to address the prominent issues of homophobia, academic performance, and activism that we discovered in our review of scholarship. We draw primarily on qualitative work out of respect for research methods that accomplish particular work in the world, work that is the articulated mission of this issue, because qualitative methods are most effective at capturing and making sense of people's unique accounts, voices, and perspectives. No other kind of research does this more powerfully. There are places, however, in our review, where we draw on quantitative studies. These are included in an effort to contextualize the qualitative accounts. There are other places where we reference journalistic texts. We recognize these as nonscholarly, but believe they make a significant contribution to our understanding of LGBTQ students in schools in cities, because they accomplish what most scholarship on LGBTQ students does not: centering sexual identity and gender expression alongside, rather than instead of, race, class, religion, social geography, and political economy. This contribution is so significant because in current scholarship, queer youth in urban schools are not being viewed in their proper contexts. Overall, our purpose is to listen to voices presented in multiple and variable texts to figure out how context matters. In doing this work, we are repeatedly reminded of the importance of intersectionality, a theorization of people's experiences growing out of multiple categories of differences, including, but not limited to, social geography. This theoretical reminder undergirds our discussion of the power struggles that occur to define and maintain space for social support, academic achievement, and activism.

\section{Homophobia}

Even with the rich resources to support gay life available in many urban communities, youth in cities across the United States continue to report school environments rife with homophobia. Such environments are the result of verbal and physical abuse enacted by homophobic students and the perpetuation of such abuse by the failure of adults in schools to address such abuse. These environments are exacerbated by adults in schools who overtly exhibit homophobia.

That homophobic students verbally and physically abuse LGBTQ youth in US schools is well documented by the GLSEN study (Kosciw et al., 2008), which found $86.2 \%$ of LGBT students experience verbal harassment because of their sexual orientation and $66.5 \%$ because of their gender expression (p. xii). It also found that $44.1 \%$ of LGBT students report having been physically harassed because of their sexual orientation and $30.4 \%$ because of their gender expression. Moreover, $22.1 \%$ of this population reported being physically assaulted because of their sexual orientation and $14.2 \%$ because of their gender expression (p. xiii). It is worth noting, though, that the GLSEN study is not limited to urban schools; only $32.4 \%$ of LGBTQ students 
who responded to GLSEN survey characterize their schools as urban (p. 11).

To illustrate that such homophobic abuses are occurring in urban schools, we turn to accounts captured by qualitative studies. For example, in the Bay Area, which is renowned for being queerfriendly, David, who was a Black gay male, said, "People used to think I was a girl and I used to get teased a lot because of that.... People eventually started throwing things at me and shit" (McCready, 2004b, pp. 138-139). Somkiat, a gay student who attended a racially diverse Midwestern city school and was not out (openly gay), described his daily experience this way:

Everyday they make fun of me and stuff. They call me "gay" and "faggot" and stuff. And, when I'm in class, people, guys don't want to sit by me because they think I'm going to touch them and whatever.... When I'm late for class, I really don't want to go in because I'm scared [that] when I walk in they'll make fun of me. They always do that. My teacher, she sees it too. She always talks to me after class is up.... I feel like there's nobody there to protect me. (Ngo, 2003, p. 118)

The harmful affect of Somkiat's classmates' homophobia is accentuated by his teacher's inability to confront such hatred.

Dylan, an out gay student in Atlanta, Georgia, experienced homophobia like Somkiat, only it was made worse by school officials' failure to address the hatred:

One day in the parking lot outside his school, six students surrounded [Dylan] and threw a lasso around his neck, saying, "Let's tie the faggot to the back of the truck."... The school took no action to discipline Dylan's harassers. Instead, school officials told him not to discuss his sexual orientation with other students.... After the lasso incident, the harassment and violence intensified.... "It gave permission for a whole new level of physical stuff to occur." (Human Rights Watch, 2001a, p. 1)

The tendency of school officials to fail to address homophobic abuse is also documented by GLSEN's school climate survey (Kosciw et al.,
2008). According to this report, when LGBT students told school staff about "incidents of victimization, students most commonly said that no action was taken" (p. 41). Although this finding was more pronounced for suburban, small town, and rural schools, even in urban schools, only " $21.7 \%$ of students ... said that school staff intervened most of the time or always when hearing homophobic remarks" (p. 71).

Moreover, GLSEN found that $59.7 \%$ of LGBT youth reported hearing homophobic language and $67.7 \%$ reported hearing biased language about gender expression from teachers or other school staff. Although this statistic was not analyzed by GLSEN according to locale, and the dynamic has not been the focus of qualitative studies of LGBTQ youth in urban schools, that urban school officials exhibit overt homophobia has been captured in newspapers. For example, Marion Bolden, the superintendent of Newark Public Schools, made the executive decision to black out a photo of Andre Jackson, a senior, kissing his boyfriend in the school yearbook. Ms. Bolden said she thought the photo was suggestive, but Jackson said, "I didn't intend to say 'Oh hey, look at me, I'm gay.' It was just a picture showing my emotion, saying that I'm happy you know. It was to look back on as a memory" ("Gay pair's photo," 2007). In Memphis, Tennessee, principal Daphne Beasley went as far as to make a list of student couples to see who was engaging in public displays of affection, and when she came across the names of two gay male students, she outed them or disclosed their sexual identity to their parents. One of the outed students, Nicholas (last name omitted) said it was "frightening to see a list with my name on it where not just other teachers could see, but students as well ... I really feel that my personal privacy was invaded. I mean, Principal Beasley called my mother and outed me to my mother!" (Friedman, 2008). Although Bolden and Beasley seem to err in opposite directions, both could have served their students better if they had more nuanced understandings of their students' (dis)comfort with their sexual identities.

Overall, it seems LGBTQ youth experience homophobia in urban schools from students and 
staff, and school staff members do not excel, relative to their nonurban counterparts, at addressing the abuse. This is made even more significant by the fact that such abuse impacts the academic performance of this population.

\section{Academic Performance}

That homophobic school climates negatively impact the scholastic achievement of queer youth and supportive school climates have the opposite effect are both documented by GLSEN's most recent school climate survey (Kosciw et al., 2008). With respect to homophobic school climates hindering academic achievement, this study found that the reported grade point average of students who were more frequently harassed because of their sexual orientation or gender expression was signi?cantly lower than for students who were less often harassed (p. 84). In terms of supportive school climates strengthening academic achievement, the same study found:

Students who were out to all students and staff at their school reported a greater sense of belonging to their school community than those who were not out.... [And] having a greater sense of belonging to one's school is related to greater academic motivation and effort as well as higher academic achievement. (Kosciw et al., 2008, p. 89)

Again, these findings are not uniquely pertinent to urban students. (As a reminder: Approximately one third of survey respondents described their schools as urban.) The following accounts, however, are focused on students in schools in cities, and they highlight the former dynamic, that is, homophobic schools hinder the academic achievement of LGBTQ students.

Teddy in San Francisco and Kira in Philadelphia both reported being good students before coming to know themselves and/or being known as not-straight. Teddy, a Filipina-American, Catholic student, withdrew from school when she came to understand herself as lesbian her junior year. She was not out to anyone else, but she struggled with internalized homophobia:

I loved school. I excelled academically until high school.... However, in my third year, my grades dropped dramatically, I stopped going to classes for weeks at a time, and I just barely graduated. What changed? I realized I was a lesbian in my junior year. I was depressed and withdrew from interacting with my friends from school. Mostly, I would skip class to spend my days in a park alone with a book or my guitar. Although there were a few on-campus resources for queer youth, they were never announced publicly and I never knew of them. I never told anyone I was lesbian until I was twenty. (Consolacion, 2001, p. 84)

Whereas Teddy's educational success was hindered by her internalized homophobia, Kira, a biracial, working-class dyke raised by an African American foster mother, was a strong student whose schooling was thwarted by homophobia. Kira attended a magnet high school for the arts in Philadelphia, the type of school depicted as safe for queer teens in popular media such as the Hollywood film Fame. For Kira, however, it was difficult to find a peer group, and the isolation brought on by not having friends eventually caused her to leave school:

I had friends that just stopped talking to me and never explained why.... I didn't really care that I didn't have any more friends. I just wouldn't, I just wouldn't go to school.... It's really hard to sit at a lunch table if you don't talk to anybody.... When you go to the same school for four years, and then, your senior year, you're alone, you're just like, 'ok,' so you don't go to lunch, then, eventually, you just don't go to school. (Blackburn, 2003, g[43)

As these voices of queer youth in urban schools reveal, homophobia negatively affects academic performance. Although some queer youth leave school for good as a result of the hatred they experience, others return later, or never leave at all, instead choosing to stay and make space for themselves (Blackburn, 2003; McCready, 2007). 


\section{Activism}

School-aged young people, responding to race-, gender-, and sexuality-based oppression, have served as the catalyst for several new social movements in America's cities, including Black Power, Women's Rights, and Gay Rights. Even the first GSA can be traced to a group of students at New York City's George Washington High School who, in 1972, founded the first schoolbased gay group on record in the United States (Johnson, 2007). Queer youth in urban schools continue this activism today through professional development, official curricula, and GSAs.

David, for example, designed professional development sessions on meeting the needs of queer students. When he returned to his Bay Area high school, he parlayed his experience working at a local queer youth center into antihomophobia workshops and panel presentations for administrators. He said, "To be able to sit up in front of the administrators and talk about my experiences was really something. After that I became even more vocal in classrooms, voicing my opinion" (McCready, 2001, p. 50).

Queer youth also find ways to make space to assert themselves and work against homophobia within the official curricula of schools. Justine, a middle-class, lesbian, African American student at the same urban magnet high school that Kira attended, brought a lesbian love poem from the queer youth center where she spent time, and photos from a lesbian history book of her own to school for a class project (Blackburn, 20022003). Thus, she found ways to make space within the parameters of her curricula by including materials and information about herself as a lesbian, which, in turn. educated her classmates and teachers about the lives of queer people.

Another way queer students in urban schools engage in antihomophobia work is through GSAs. Lee's (2002) study of a GSA in Salt Lake City captured youth voices naming several benefits of their GSA, with safety being one the most important. For example, Erin, who is implicitly identified as lesbian when she refers to the gay community as her community (p. 22), said, "I personally feel a lot less scared, because of the group. Because we have numbers now. Because we are visible" (p. 21). Erin, among others, also reported improved relationships with "administrators, teachers, family and peers" (p. 18) as a result of their participation in the GSA. She said, "I feel more willing to identify with a diversity of people at school. Now I feel rooted in who I am. I can go talk to other people. I don't need to wimp out" (p. 18). In addition to feeling safer and sharing better relationships with people at school, and perhaps because of these things, the students in the GSA asserted that their academic performance improved as a result of their participation in the club. For example, Kelli, a lesbian, said:

I faced a lot of harassment being one of the only "out" students at East High School before the club. And I was terrified to go to school. I avoided going to school. I failed most of my classes my freshman through junior year. My senior year I attended regularly and held down the best GPA I've had since I've been in school. (Lee, 2002, p. 17)

The experiences of young people in Salt Lake City suggest that GSAs hold tremendous promise as organizations that support the development of queer youth in schools. This finding is supported by GLSEN's most recent school climate survey (Kosciw et al., 2008).

However, there is a growing number of studies of GSAs that suggest that queer youth who attend urban schools in non-White, multiracial, poor, and working class communities experience difficulty starting and/or accessing their schools' GSAs. For example, McCready's (2004a) study of Project 10, which functioned as a GSA at a Bay Area high school, revealed the shortcomings of this club when it came to meeting the needs of queer students of color. Jamal and David both described the club as inaccessible because it was "under surveillance by their heterosexual Black peers" (p. 42). "Jamal believed these dynamics were particularly evident when students read the daily Bulletin announcing school-wide events, including Project 10" (p. 42). When Jamal was in predominantly White classes, Project 10 announcements would be read aloud with little 
event, but when a similar announcement was read in predominantly Black classes, Jamal said,

They would skip over it like the club did not exist. They would either speak through it, or it was just treated differently than the other club announcements.... There was a running joke at school, like people wanted to go and see who actually went to the club.... Like you don't want to be seen walking up to the third floor on the day that Project 10 is meeting. (McCready, 2004a, p. 43)

Even when a student of color like David endured the scrutiny to attend a Project 10 meeting, he felt alienated and excluded. He called the group "a select group of White girls ... just teatime for a few lesbians and their friends.... I went two consecutive weeks and then I stopped going because it wasn't doing anything for me. There's nothing there for me" (p. 45). Because of these dynamics, which McCready theorized stem from racial segregation and the normalization of Whiteness, the GSA, at least at this school, failed to meet the needs of queer students of color.

Quinn's study of queer girls of color starting a GSA at an all-girls public charter middle- and high school in Chicago points to different though equally troubling social and cultural dynamics related to leadership and participation. The group started to create, formally, a space for socializing and support:

At first we used to just ... talk to a counselor ... 'cause everybody was pretty much in the closet, and ... just we only knew who was gay or not.... And then after that, it seemed like somebody thought of a GSA. And then from then on, it just snowballed. (Quinn, 2007, p. 35)

When parents heard about the GSA from their children, some organized to oppose the group because they believed it was immoral, that students in middle school were too young to hear about the group, and it might cause them to question their sexuality. School administrators initially dismissed objections to the GSA; however, as the controversy unfolded, flyers announcing GSA activities were defaced and removed from the school's bulletin boards, the pressure on administration became too great and the GSA was disbanded. Although the group was reinstated a year later, Quinn noted that at this school,

lesbian students claimed both cultural and sexual specificity by acting as loud black and often masculine girls. They rejected conformity to norms of leadership valued in the school and society - both raced and gendered-when they acted assertively and collectively to start the GSA. (p. 42)

In this way, these girls challenged the notion that GSAs are for White girls and troubled the idea of what school leaders can look and be like.

We acknowledge the significant activist efforts by LGBTQ youth in the forms of professional development, official curricula, and GSAs, but we are concerned about how GSAs, in particular, seem to be inadequate for LGBTQ youth of color. The importance of this shortcoming is underscored by the GLSEN finding that even though LGBT students attending schools in cities were less likely than those in schools in suburbs, small towns, or rural areas to hear homophobic remarks and to experience victimization based on sexual orientation, they were more likely to experience victimization based on race or ethnicity.

\section{Conclusions and Implications}

Overall, the experiences of queer youth in urban schools seem both similar to and different from queer youth in other locales. Ironically, despite the visibility of queer people and resources to support gay life in cities, queer youth in urban schools experience homophobia, which can both negatively affect academic performance and spark activism. These findings parallel queer youth in suburban and rural locales where there are fewer economic, social, and cultural resources devoted to queer communities. The voices of queer youth in urban schools distinguish themselves, however, by their talk of coping with the dynamics of racism and race, as discussed above, and class stratification and immigration 
in the city, as discussed below. These voices, both loud and quiet, have important implications for reimagining the lives of queer youth in urban schools.

Queer youth in urban communities, who are increasingly non-White, immigrant, and attending schools in lower-income, underresourced communities, experience a multitude of oppressive forces that stem from their social identities as people of color, non-standard English speakers, non-Christians, and gender nonconformists, to name a few. If one takes these social, cultural, and economic dynamics into account, it becomes clear that, to work effectively with queer youth in urban communities, one has to embrace the complexities of their multiple identities and develop the capacity to understand the intersections among them. Quincy, a Caribbean student in a New York City high school, described the impact of embodying multiple stigmatized social identities:

I really hated myself for quite some time. I think because of just all the things that make, make up who I am-my, my sexuality, I hated that. My skin color, I guess being an immigrant. Um, because from kindergarten until probably like my third year in high school, people just made fun of me ... From all of that talking and teasing my self-esteem was like, you know, nil. (Spain, 2001, p. 106)

Here, Quincy underscored the importance of his race, ethnicity, language, and immigrant status, in addition to his sexuality. It seems Quincy's challenges, like many queer youth in the city, parallel a larger set of developments in many dimensions of urban life. The increasing diversity of metropolitan centers due to immigration suggests that in the 21 st century many more queer youth will identify as non-White, nonnative speakers of English who understand their sexual identity from a non-Western or, at the very least, dual cultural frame of reference. The increased visibility of non-White queer youth, however, does not mean they are more readily accepted within their neighborhoods and schools. Wright (2008) provided several compelling portraits of queer youth of color who live in New York City, but remain isolated in terms of queer life in the predominantly Black and Latino Brooklyn neighborhood where they live.

Moreover, queer youth in urban communities who grow up in non-Western countries may understand their sexuality in vastly different ways than Western youth. For example, in some African and South Asian countries, homosexuality is illegal. Non-Western languages may or may not have specific words for nonheterosexual identities that connote the same meanings as the Western sense of gay, lesbian, bisexual, or transgender. Urban LGBTQ youth who are nonWhite and/or immigrants experience tremendous isolation amidst the wealth of resources for LGBTQ youth when they live in communities that condemn homosexuality for cultural and religious reasons. These youth may also experience isolation when they identify and/or express their sexual identities in Western ways.

In addition to cultural barriers, queer youth in US cities, specifically, are experiencing massive resegregation of public schools due, in part, to segregated housing patterns and the waning commitment of the federal government to enforce court-ordered desegregation in the 21 st century. Essentially, what this means is a return to neighborhood schools in urban communities that are racially segregated, and, in most cases, areas of concentrated poverty, as well. Racially segregated schools in communities where the median family income is below average are less likely to have programs specifically aimed at queer youth; there simply are not enough economic resources to support such efforts.

In keeping with the claim that the experiences of queer youth in urban schools seem both similar to and different from queer youth in other locales, the implications for educators in urban schools working with LGBTQ students are both similar to and distinct from implications for educators with these populations in nonspecified contexts. Such implications include (a) developing policies that support LGBTQ students, teachers, and staff and penalize homophobia; (b) providing training that teaches teachers, counselors, administrators, and other support staff how to support LGBTQ students and to prevent and intervene homopho- 
bic behaviors; (c) providing current resources about LGBTQ people and the issues that impact them in both public and private ways, through counselors, nurses, social workers, psychologists, and media specialists; and (d) ensuring access to both curricular and extracurricular supports for LGBTQ people (Human Rights Watch, 2001b). Although these serve as a decent starting point, they must be more nuanced to be useful in urban contexts.

In short, urban educators working with queer youth need to understand and be prepared to address multiple social and cultural issues that intersect with sexual and gender identities. This necessitates an intersectional analysis. Intersectionality can be defined as a theory to analyze how social and cultural categories of identity and oppression are interconnected. Moreover, McCready (2007) reminds us that in-school efforts such as those suggested above are often hindered by urban educators' ambivalence about the "relevance of anti-homophobia to their social justice work in urban schools" (p. 74). So, this obstacle must be overcome and the opportunity to grapple with the complicated notion of intersectionality must be embraced.

In terms of policy-development, this may mean, for example, ensuring confidentiality so that students whose family values emphasize heterosexuality and gender normativity are not made more vulnerable by reporting abuse. Trainings should include education about particular populations in the school and the stances taken on homosexuality and gender expression within these populations. In other words, notions of right and wrong should be rejected and replaced with complicated ideas that recognize multiplicity and variability within the school community. Resources should be available in the languages spoken by the various student populations within the school, and they should represent diverse peoples and communities. Curricular materials should be similarly representative, and extracurricular efforts, such as GSAs, should be recognized both for what they do and do not accomplish in urban schools. When GSAs prove to inadequately serve the school's populations, for example, alternatives should be generated from students and facilitated, indeed nurtured, by adults in the school. Rather than being seen as a burden, intersectionality should be viewed as opportunity-rich in terms of shaping policy and providing training, resources, and curricular and extracurricular supports.

One of the most exciting tasks for 21 st century urban educators who work with queer youth will be to develop comprehensive approaches to their work, approaches that take into account how the social, cultural, and economic dynamics of the city affect queer youth programs and services. A good example of this work is the Respect Campaign (RC) launched by Out for Equity in eight Saint Paul, Minnesota, schools. RC was a two-year project including 12 schools that served to "identify obstacles to a respectful school climate, develop a vision for positive change, chart and implement a course of action and evaluate success" (Horowitz \& Itzkowitz, 2007, p. 3). The project reveals an understanding that students in urban schools face multiple forms of oppression and discrimination that can make school feel unsafe. Based on this understanding, RC helped urban educators develop a multidimensional framework of a healthy school climate, one that addresses issues of homophobia and heterosexism, but also takes into account oppression and discrimination based on race, ethnicity, class, gender, and religion. Such work provides a model for the kind of work that would better meet the needs of queer youth in urban schools.

\section{References}

Blackburn, M. V. (2002-2003). Disrupting the (hetero)normative: Exploring literacy performances and identity work with queer youth. Journal of Adolescent \& Adult Literacy, 46, 312-324.

Blackburn, M. V. (2003). Losing, finding, and making space for activism through literacy performances and identity work. Penn GSE Perspectives on Urban Education, 2(1). Retrieved June 8, 2009 from http://www.urbanedjournal.org/articles/article 0008.html

Blackburn, M. V. (2004). Understanding agency beyond school-sanctioned activities. Theory Into Practice, 43, 102-110. 
Cohen, H. S. (Producer), \& Chasnoff, D. (Producer \& Director). (1997). It's elementary: Talking about gay issues in school [film]. San Francisco, CA: Women's Educational Media.

Consolacion, T. (2001). Where I am today. In K. Kumashiro (Ed.), Troubling intersections of race and sexuality: Queer students of color and antioppressive education (pp. 83-85). Lanham, MA: Rowman and Littlefield.

Friedman, E. (2008, May 2). Principal allegedly outs gay students. ABC News. Retrieved June 8, 2009 from http://abcnews.go.com/US/Story?id=477338 $1 \&$ page $=1$

Gay pair's photo blacked out of yearbook. (2007, June 22). The Star Ledger. Retrieved June 8, 2009 from http://www.nj.com/news/index.ssf/2007/06/ gay_pairs_photo_blacked_out_of_1.html

Horowitz, A., \& Itzkowitz, M. (2007, October). Out for equity middle school project. Out for Equity Newsletter, pp. 1, 3, 4, 10.

Human Rights Watch. (2001a). Hatred in the hallways: Violence and discrimination against lesbian, gay, bisexual, and transgender students in U.S. schools. New York: Author.

Human Rights Watch. (2001b). Hatred in the hallways: Violence and discrimination against lesbian, gay, bisexual, and transgender students in U.S. schools. American Journal of Health Education, 32, 302306.

Johnson, D. (2007). "This is political!" Negotiating the legacies of the first school-based gay youth group. Children, Youth and Environments, 17, 380-387.

Kosciw, J. G., Diaz, E. M., \& Greytak, E. A. (2008). The 2007 National School Climate Survey: The experiences of lesbian, gay, bisexual, and transgender youth in our nation's schools. New York: Gay, Lesbian and Straight Education Network.

Lee, C. (2002). The impact of belonging to a high school gay/straight alliance. High School Journal, 85(3), 13-26.

McCready, L. T. (2001). When fitting in isn't an option, or, Why Black queer males at a California high school stay away from Project 10 . In K. Kumashiro (Ed.), Troubling intersections of race and sexuality: Queer students of color and antioppressive education (pp. 37-53). Lanham, MA: Rowman and Littlefield.

McCready, L. (2004a). Some challenges facing queer youth programs in urban high schools: Racial segregation and de-normalizing Whiteness. Journal of Gay and Lesbian Issues in Education, 1(3), 3751.

McCready, L. T. (2004b). Understanding the marginalization of gay and gender non-conforming Black male students. Theory Into Practice, 43, 136-143.

McCready, L. T. (2007). Queer urban education: Curriculum and pedagogy for LGBTQI youth in the city. Journal of Curriculum and Pedagogy, 4(2), 71-77.

Milwaukee to form gay-friendly middle school (2008, December 17). U.S. news and world report. Retrieved June 8, 2009 from http://www.usnews. com/blogs/on-education/2008/12/17/milwaukee-toform-gay-friendly-middle-school.html

Ngo, B. (2003). Citing discourses: Making sense of homophobia and heteronormativity at Dynamic High School. Equity and Excellence in Education, 36, 115-124.

Quinn, T. M. (2007). "You make me erect!": Queer girls of color negotiating heteronormative leadership at an urban all-girls' public school. Journal of Gay and Lesbian Issues in Education, 4(3), 3147.

Spain, C. R. (2001). An interview with Quincy Greene. In K. Kumashiro (Ed.), Troubling intersections of race and sexuality: Queer students of color and anti-oppressive education (pp. 105-108). Lanham, MA: Rowman and Littlefield.

Uribe, V. (1995). A school-based outreach to gay and lesbian youth. In G. Unks (Ed.), The gay teenager (pp. 203-210). New York: Routledge.

Wright, K. (2008). Drifting toward love: Black, brown, gay, and coming of age on the streets of New York. Boston: Beacon Press. 